\title{
A Simple Numerical Model for Studying Cloud Formation Process in the Tropics : Heated and cooled surface experiments
}

\author{
CHANTAWAN NOISRI \\ Department of Mathematics \\ Faculty of Science, Thaksin University \\ Phatthalung, THAILAND
}

\begin{abstract}
A simple numerical model for demonstrating local cloud formation processes in the tropics is being developed. The model equations are derived from the fundamental system of partial differential equations of computational fluid dynamics and the deep convection approximation is used to eliminate sound waves. The model domain is two-dimensional with length100 kilometers and height 17.5 kilometers. A non-uniform grid is used with the thinnest layer (100 meters) at the earth's surface and thickest layer (1,300 meters) at the top of the troposphere. The horizontal cell's width one kilometer. The Arakawa-C grid is used for the leapfrog method and forward Euler method. Experiments to study the effects of heating and cooling at the surface and the deep convection approximation in moist air are discussed. The deep convection approximation was found to be unsuitable for a model. The model without the deep convection approximation gives processes expected in the real atmosphere.
\end{abstract}

Key-Words: Cloud formation; Surface heating; Surface cooling; Deep convection; Finite differences.

Received: August 29, 2020. Revised: November 21, 2020. Accepted: November 30, 2020. Published: December 12, 2020.

\section{Introduction}

Numerical weather prediction (NWP) models are techniques used to predict the future state of the weather by solving a set of equations which govern the behavior of the atmosphere. The models used today for research and operational weather forecasting are very large and complicated. They can be understood by professional meteorologists only after long periods of study. The physical processes in the climate system span an enormous range of spatial and temporal scales, and even understanding the process of small-scale convective cloud in the atmosphere is complicated. The simplified numerical model described in paper has been done for teaching purposes.

A simple numerical model in dry air with horizontal grid steps of $1 \mathrm{~km}$ has shown by experiments that a time step of

seconds is too large for the model without the deep convection approximation [1]. But with the deep convection approximation one can use a time step of seconds and get reasonable results in numerical experiments on the vertical movement of air over a heated surface representing a city heat island [2]. Time steps of 0.2 seconds and seconds are used, give stable results for the model without the deep convection approximation and the model with the deep convection approximation, respectively [1]. The same results, a simple numerical model in moist air has shown that a time step of 0.3 seconds is too large for the model without the deep convection approximation but the model with the deep convection approximation can use a time step of 0.4 seconds [3].

\section{Model Discription}

In the model there is one horizontal dimension, the vertical dimension, and the time dimension. The variables are located on a staggered grid with stretched grid spacing in the vertical dimension and constant grid spacing in the horizontal dimension.

The molecular viscosity terms are omitted; the body forces are friction at the Earth's surface in the horizontal momentum equation and gravity in the vertical momentum equation; heating and cooling of the air occur at the Earth's surface; kinetic energy and potential energy in the temperature equation are omitted; the Coriolis force is omitted; no distinction is made between liquid water and ice; the effects of the moisture on the thermodynamic properties of the air are neglected; rain is not included; and the deep convection approximation is used.

The deep convection approximation [4] is

$$
\frac{\partial u}{\partial x}+\frac{\partial w}{\partial z}=-\frac{w}{\rho^{0}} \frac{\partial \rho^{0}}{\partial z},
$$

where $\rho^{0}$ is calculated from a steady background temperature profile and the assumption of hydrostatic equilibrium in the undisturbed atmosphere.

The steady background temperature profile is an approximation to the annual mean upper air temperatures at Bangkok represented by the formula

$$
T^{0}=302-0.00675 z
$$

where $T^{0}$ is in kelvins 
TABLE I. LIST OF SYMBOLS

\begin{tabular}{|c|l|}
\hline Symbol & \multicolumn{1}{|c|}{ Description } \\
\hline$x$ & Horizontal distance \\
\hline$z$ & Vertical height \\
\hline$t$ & Time \\
\hline$g$ & Acceleration of gravity \\
\hline$R$ & Gas constant for air \\
\hline$c_{v}$ & Specific heat of air \\
\hline$\rho$ & Air density \\
\hline$u$ & Horizontal velocity \\
\hline$w$ & Vertical velocity \\
\hline$T$ & Temperature \\
\hline$z_{0}$ & Roughness length of the surface \\
\hline$q_{s}$ & Surface heating rate per unit area \\
\hline$\rho_{s} k$ & Horizontal and vertical cell indices \\
\hline$\rho_{s}$ & Saturated vapor density \\
\hline$L$ & Water vapor density \\
\hline & Condensed cloud water per unit volume \\
\hline$m_{c}$ & Latent heat of condensation of water \\
\hline & \\
\hline &
\end{tabular}

\subsection{Governing Equations}

The model equations listed below are derived from the fundamental system of partial differential equations of computational of fluid dynamics [5]. The temperature and moisture equations used depend on whether or not the air is saturated. A simple equation for the saturation vapor density of water as a function of temperature is obtained by integrating the Clausius Clapeyron equation [6] assuming that the latent heat of condensation of water vapor is constant and water vapor is an ideal gas.

\section{The density equation}

The density equation without the deep convection approximation is

$$
\frac{D \rho}{D t}=-\rho\left(\frac{\partial u}{\partial x}+\frac{\partial w}{\partial z}\right)
$$

and the density equation with the deep convection approximation is

$$
\frac{D \rho}{D t}=-\rho \frac{w}{T^{0}}\left(\frac{\partial T^{0}}{\partial z}+\frac{g}{R}\right)
$$

The vertical velocity equation

$$
\frac{D w}{D t}=-\frac{R T}{\rho} \frac{\partial \rho}{\partial z}-R \frac{\partial T}{\partial z}-g
$$

The wind equation

$$
\frac{D u}{D t}=-\frac{R T}{\rho} \frac{\partial \rho}{\partial x}-R \frac{\partial T}{\partial x}-\frac{0.16 u|u|}{\left[\ln \left(0.5 \Delta z / z_{0}\right)\right]^{2} \Delta z}
$$

The last term is horizontal friction, which is applied only in the layer of air of thickness $\Delta z$ at the Earth's surface where the roughness length is $z_{0}$

\section{Unsaturated air}

The temperature equation

$$
\frac{D T}{D t}=-\frac{R T}{c_{v}}\left(\frac{\partial u}{\partial x}+\frac{\partial w}{\partial z}\right)+\frac{q_{s}}{c_{v} \rho \Delta z}
$$

The surface heating term is applied only in the layer of air at the Earth's surface.

The water vapor equation

$$
\frac{D \rho_{v}}{D t}=-\rho_{v}\left(\frac{\partial u}{\partial x}+\frac{\partial w}{\partial z}\right)
$$

The condensed cloud water equation

$$
m_{c}=0
$$

\section{Saturated air}

The temperature equation

$$
\frac{D T}{D t}=\frac{W}{1+E Q}
$$

The water vapor equation

$$
\frac{D \rho_{v}}{D t}=\frac{E W}{1+E Q}
$$

The condensed cloud water equation

$$
\frac{D m_{c}}{D t}=-\left(\rho_{v}+m_{c}\right)\left(\frac{\partial u}{\partial x}+\frac{\partial w}{\partial z}\right)-\frac{E W}{1+E Q}
$$


where $\quad W=-\frac{R T}{c_{v}}\left(\frac{\partial u}{\partial x}+\frac{\partial w}{\partial z}\right)+\frac{q_{s}}{c_{v} \rho \Delta z}$

$$
\begin{aligned}
& E=\frac{A(B-T)}{R_{v} T^{3}} e^{-B / T}, \\
& Q=\frac{L}{c_{v} \rho}, L=2.50 \times 10^{6} \mathrm{Jkg}^{-1} .
\end{aligned}
$$

\subsection{Finite difference set up}

The domain of the model is divided into a $25 \times 100$ array of cells. The horizontal resolution is one kilometer. A vertical coordinate $s$ is used in accordance with the transformation $z=75 s+25 s^{2}$ in order to give thin layers at the Earth's surface and thick layers at the top of the troposphere [7]. The model variables are evaluated at points on an Arakawa-C grid. The horizontal velocity is on the left side of the cell, the vertical velocity is on the bottom of the cell, and other variables are in the center of each cell, as shown in Fig1.

The leapfrog method is used to calculate the model variables at next time step. The Euler method is used for the first time step. First and second order finite difference approximations are used in the modeling of space derivatives. In the row of cells at the Earth's surface one-sided second order difference approximations to derivatives with respect to $z$ are used.
The initial values of the model variables in each cell are functions of the height of the cell above the Earth's surface, but are constant along the horizontal rows of cells. The temperature equation is given by

$$
T_{k}^{0}=302.211-0.3375 k-0.16875 k^{2},
$$

where $k=1,2, \ldots, 25$.

It is assumed the initial values of the velocity, surface heating and amounts of cloud water are zero everywhere. The initial values of the temperature and density satisfy the hydrostatic equation, and the initial values of vapor density are calculated on the assumption that the dew point depression below the initial air temperature is a constant at all heights. The model variables are fixed at the boundary.

\subsection{Numerical Experiments}

Four different experiments were done on the performance of the model in various cases as given below to study the effects of a heated area and cooling area in the middle of the domain:

- A heated area in the middle of the domain in the model without the deep convection approximation.

- A heated area in the middle of the domain in the model with the deep convection approximation.

- A cooling area in the middle of the domain in the model without the deep convection approximation.

- A cooling area in the middle of the domain in the model with the deep convection approximation.

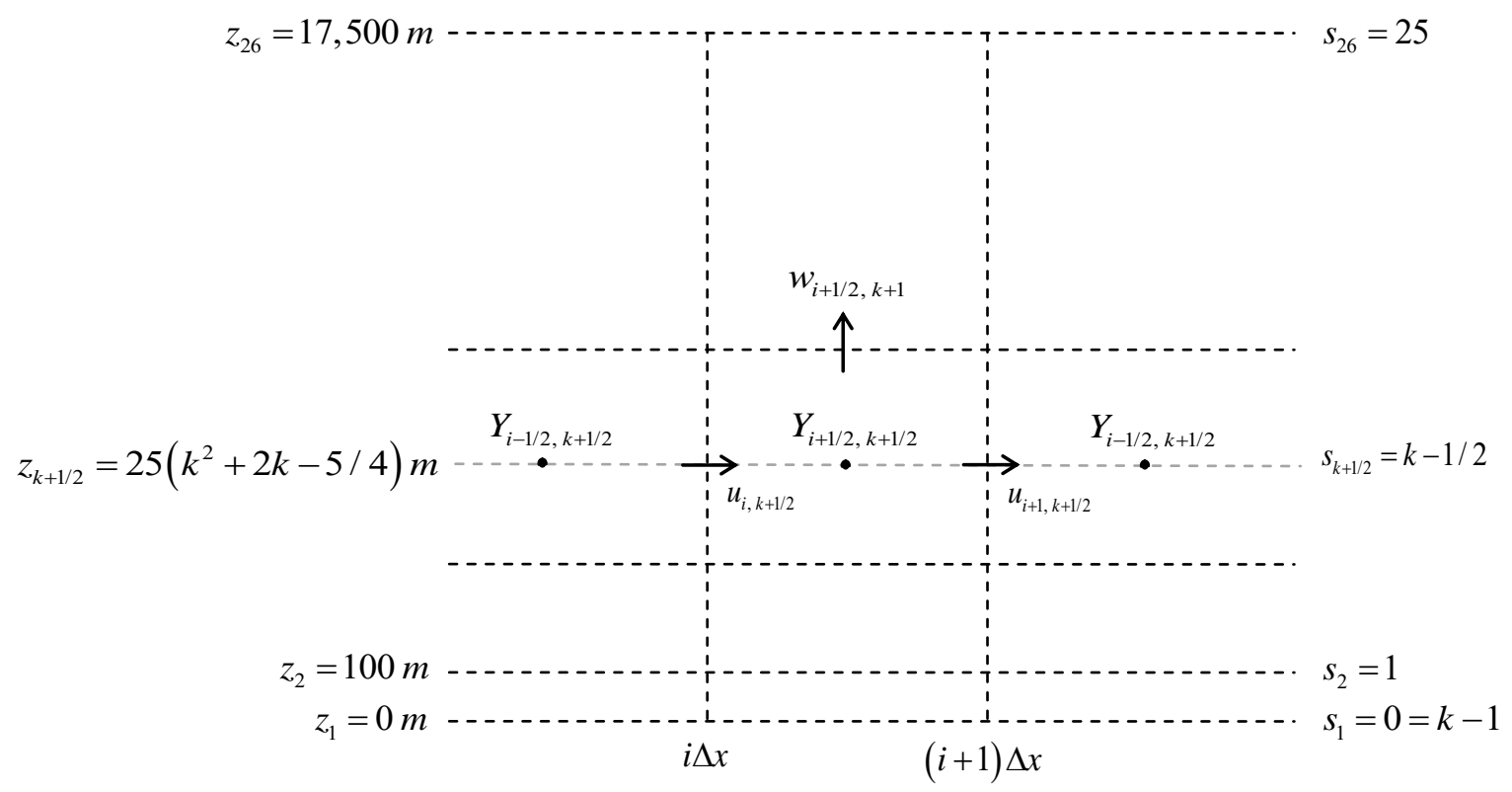

Fig. 1. The model variables are evaluated on an Arakawa-C grid with the stretched grid. The horizontal velocity is on the left side of the cell, the vertical velocity is on the bottom of the cell, and other variables are in the center of each cell. 


\section{Results and Discussion}

Experiments with heating and cooling at the earth's surface to examine the convection and cloud produced. Main objective is to find the vertical velocities and cloud water amounts given by the model in these experiments and determine whether or not they are similar to vertical velocities and cloud water amounts observed in real clouds.

TABLE II. OBSERVED MAGNitudes of THE Vertical Velocity AND Cloud Water [6].

\begin{tabular}{|l|c|c|}
\hline & Normal Low Cloud & Thunderstorm \\
\hline Vertical Velocity & $\sim 1 \mathrm{~m} \mathrm{~s}^{-1}$ & $\sim 10 \mathrm{~m} \mathrm{~s}^{-1}$ \\
\hline Cloud Water & $\sim 0.1 \mathrm{~g} \mathrm{~m}^{-3}$ & $\sim 1 \mathrm{~g} \mathrm{~m}^{-3}$ \\
\hline
\end{tabular}

\subsection{Heated Surface Experiments}

To study the vertical motion of the air with heating in the surface layer (due to solar radiation heating), the initial and boundary conditions are as following:

- The horizontal and vertical velocities are zero everywhere.

- Boundary values are fixed the same as initial values.

- The surface heating in the middle of the domain is shown in Fig. 2 defined by the equation:

$$
q_{s}(i)=q^{*} e^{-\frac{(i-50.5)^{2}}{100}}
$$

where $q_{s}$ is in $\mathrm{W} \mathrm{m}^{-2}, q^{*}$ is the highest heat which is $500 \mathrm{~W} \mathrm{~m}^{-2}$, and $i$ is the horizontal cell index.

- The earth's surface is smooth (surface roughness $z_{0}$ is $0.01 \mathrm{~m})$.

- The temperature lapse rate $\gamma$ is $0.00675 \mathrm{~K} \mathrm{~m}^{-1}$.

- The dew point depression is $\delta=0.16 \mathrm{~K}$ at all heights.

- Time steps 0.2 second and 0.4 second are used in the models without and with the deep convection approximation, respectively.

The numerical method gives symmetric results. The model with the deep convection approximation in moist air gives the same results as dry air [2] with no condensation of water vapor for 56 minutes. High cloud forms after 58 minutes. Condensed cloud water in the model with the deep convection approximation is produced slower and less than condensed cloud water in the model without the deep convection approximation.

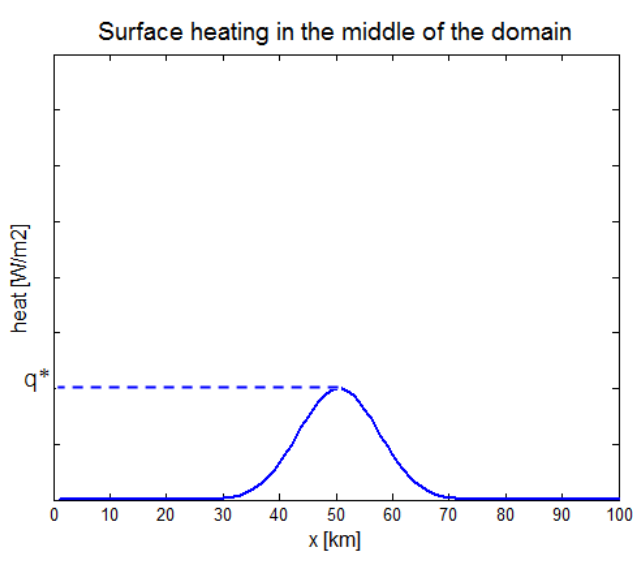

Fig. 2. The surface heating in the middle of the domain.

The warm air due to surface heating thus reduces in density and become lighter. The air at the ground level that contain water vapor begins to rise, expand, and cool. Wind circulation is produced. Clouds are formed when the humid air is cooled below a critical temperature and the water vapor condenses. Because the air is stable the circulation and cloud produced do not extend to heights above two or three kilometers.

The results show that this circulation and low clouds expected in the real atmosphere are well represented by the model without the deep convection approximation. The use of the deep convection approximation, on the other hand, gives an unreasonable circulation pattern, with velocities which are too small and clouds produce too high up in the troposphere as shown in Table III.

Tables II and IV, the model without the deep convection approximation gives the values of velocity and condensed cloud water close to observed values of velocity and cloud water. The model with the deep convection approximation gives velocities and clouds which are too small.

TABLE III. ThE Total Time, Wind CiRCUlation, MAXimum CONDENSED ClOUD WATER, AND MAXIMUM VERTICAL VELOCITY OF SURFACE HEATING EXPERIMENTS.

\begin{tabular}{|c|c|c|}
\hline & $\begin{array}{l}\text { The model without the deep } \\
\text { convection approximation }\end{array}$ & $\begin{array}{l}\text { The model with the deep } \\
\text { convection approximation }\end{array}$ \\
\hline Total time & 47 minutes & $>60$ minutes \\
\hline $\begin{array}{l}\text { Wind } \\
\text { circulation }\end{array}$ & $\begin{array}{l}\text { after } 19 \text { minutes } \\
\text { at } \sim 0.17 \mathrm{k} \mathrm{m} \text { height }\end{array}$ & $\begin{array}{l}\text { after } 33 \text { minutes } \\
\text { at } \sim 3 \mathrm{k} \mathrm{m} \text { height }\end{array}$ \\
\hline $\begin{array}{l}\text { Maximum } \\
\text { condensed } \\
\text { cloud water }\end{array}$ & $\begin{array}{c}\sim 8 \mathrm{~g} \mathrm{~m}^{-3} \text { after } 47 \text { minutes at } \\
\sim 0.17 \mathrm{k} \mathrm{m} \text { height }\end{array}$ & $\begin{array}{c}\sim 5.5 \times 10^{-6} \mathrm{~g} \mathrm{~m}^{-3} \text { after } 60 \\
\text { minutes at } \sim 15.5 \mathrm{k} \mathrm{m} \\
\text { height }\end{array}$ \\
\hline $\begin{array}{l}\text { Maximum } \\
\text { vertical } \\
\text { velocity }\end{array}$ & $\begin{array}{c}\sim 25 \mathrm{~m} \mathrm{~s}^{-1} \text { after } 47 \text { minutes } \\
\text { at } \sim 1.5 \mathrm{k} \mathrm{m} \text { height }\end{array}$ & $\begin{array}{c}\sim 1.6 \mathrm{~m} \mathrm{~s}^{-1} \text { after } 60 \text { minutes } \\
\text { at } \sim 17 \mathrm{k} \mathrm{m} \text { height }\end{array}$ \\
\hline
\end{tabular}


TABLE IV. The Condensed Cloud Water, Vertical Velocity and Height of Surface Heating Experiments.

\begin{tabular}{|c|c|c|c|c|c|c|c|c|}
\hline \multirow[b]{2}{*}{$\begin{array}{l}\text { Time } \\
{[\mathrm{min}]}\end{array}$} & \multicolumn{4}{|c|}{ The model without the deep convection approximation } & \multicolumn{4}{|c|}{ The model with the deep convection approximation } \\
\hline & $\begin{array}{c}\text { Condensed } \\
\text { cloud water } \\
{\left[\mathrm{g} \mathrm{m}^{-3}\right]}\end{array}$ & $\begin{array}{l}\text { Height } \\
{[\mathrm{k} \mathrm{m}]}\end{array}$ & $\begin{array}{c}\text { Vertical } \\
\text { velocity } \\
{\left[\mathrm{m} \mathrm{s}^{-1}\right]}\end{array}$ & $\begin{array}{l}\text { Height } \\
{[\mathrm{k} \mathrm{m}]}\end{array}$ & $\begin{array}{c}\text { Condensed } \\
\text { cloud water } \\
{\left[\mathrm{g} \mathrm{m}^{-3}\right]}\end{array}$ & $\begin{array}{l}\text { Height } \\
{[\mathrm{k} \mathrm{m}]}\end{array}$ & $\begin{array}{c}\text { Vertical } \\
\text { velocity } \\
{\left[\mathrm{m} \mathrm{s}^{-1}\right]}\end{array}$ & $\begin{array}{l}\text { Height } \\
{[\mathrm{k} \mathrm{m}]}\end{array}$ \\
\hline 39 & 0.02 & 0.2 & 0.7 & 0.3 & & & & \\
\hline 40 & 0.16 & & 1.2 & & & & & \\
\hline 41 & 0.40 & & 2 & $\vdots$ & & & & \\
\hline 42 & 0.65 & & 3 & & & & & \\
\hline 43 & 0.06 & $\vdots$ & 5 & 0.3 & & & & \\
\hline 44 & 0.18 & & 7 & 0.8 & & & & \\
\hline 45 & 0.02 & & 12 & 1.2 & & & & \\
\hline 46 & 0.80 & & 18 & 1.5 & & & & \\
\hline 47 & 8.00 & 0.2 & 25 & 1.5 & & & & \\
\hline$\vdots$ & & & & & & & & \\
\hline 58 & \multirow{3}{*}{\multicolumn{4}{|c|}{ overflow after 47 minutes }} & $6 \times 10^{-8}$ & 15.5 & 0.2 & 17 \\
\hline 59 & & & & & $1 \times 10^{-8}$ & $\vdots$ & 0.7 & $\vdots$ \\
\hline 60 & & & & & $5.5 \times 10^{-6}$ & 15.5 & 1.6 & 17 \\
\hline
\end{tabular}

\subsection{Cooled Surface Experiments}

To study the vertical motion of the air with cooling in the surface layer (due to longwave radiation cooling), the initial and boundary conditions are as following:

- The horizontal and vertical velocities are zero everywhere.

- Boundary values are fixed the same as initial values.

- The surface heating in the middle of the domain is shown in Fig. 3 defined by the equation:

$$
q_{s}(i)=-q^{*} e^{-\frac{(i-50.5)^{2}}{100}}
$$

where $q_{s}$ is in $\mathrm{W} \mathrm{m}^{-2},-q^{*}$ is the highest cool which is $60 \mathrm{~W} \mathrm{~m}^{-2}$, and $i$ is the horizontal cell index.

- The earth's surface is smooth (surface roughness $z_{0}$ is $0.01 \mathrm{~m})$.

- The temperature lapse rate $\gamma$ is $0.00675 \mathrm{~K} \mathrm{~m}^{-1}$.

- The dew point depression is $\delta=0.16 \mathrm{~K}$ at all heights.

- Time steps 0.2 second and 0.4 second are used in the models without and with the deep convection approximation, respectively.

The numerical method gives symmetric results. The model without the deep convection approximation gives fog in the middle at the surface after time 6 minutes. The maximum condensed cloud water is produced after 32 minutes and gone after 37 minutes. Condensed cloud water is not produced in the model with the deep convection approximation.
The surface in the middle of the domain is cooler than the area around it. The vertical motion of the air is produced by descending air from above. Wind circulation is produced flowing away from the middle of the cooled area at the surface into the sinking air aloft. Surface cooling makes the air more stable and cloud, which is called fog, is produced close to the surface.

The results show that this circulation and the actual wind speeds expected in the real atmosphere are represented by the model without the deep convection approximation. The model with the deep convection approximation gives unstable results after 27 minutes. Thunderstorm vertical velocities are occurred but cloud water is not produced in the model with the deep convection approximation as shown in Table V.

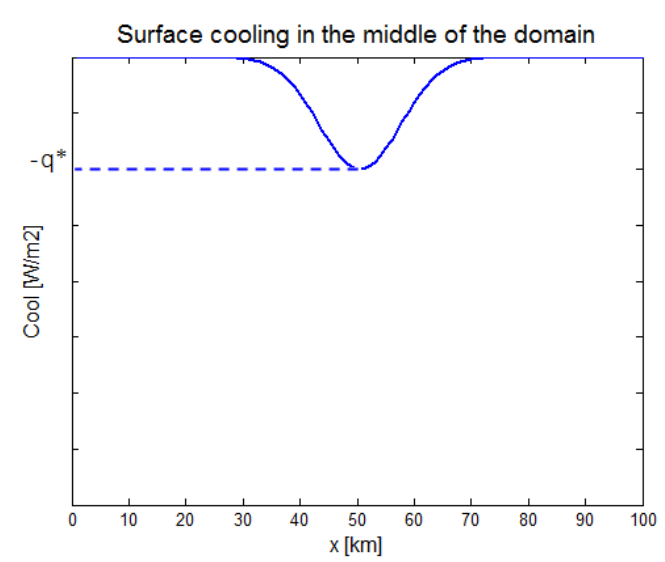

Fig. 3. The surface cooling in the middle of the domain. 
TABle V. The Total Time, Wind Circulation, MaXimum CONDENSED ClOUd WATER, AND MAXIMUM VeRTICAL VELOCITY OF SURFACE COOLING EXPERIMENTS.

\begin{tabular}{|l|c|c|}
\hline Total time & $\begin{array}{c}\text { The model without the deep } \\
\text { convection approximation }\end{array}$ & $\begin{array}{c}\text { The model with the deep } \\
\text { convection approximation }\end{array}$ \\
\hline $\begin{array}{l}\text { Wind } \\
\text { circulation }\end{array}$ & $\begin{array}{c}\text { after } 11 \text { minutes } \\
\text { at } \sim 0.6 \mathrm{k} \mathrm{m} \text { height }\end{array}$ & 27 minutes \\
\hline $\begin{array}{l}\text { Maximum } \\
\text { condensed } \\
\text { cloud water }\end{array}$ & $\begin{array}{c}\sim 0.4 \mathrm{~g} \mathrm{~m}^{-3} \text { after } 32 \text { minutes } \\
\text { at } \sim 0.17 \mathrm{k} \mathrm{m} \text { height }\end{array}$ & - \\
\hline $\begin{array}{l}\text { Maximum } \\
\text { vertical } \\
\text { velocity }\end{array}$ & $\begin{array}{c}\sim-2.5 \mathrm{~m} \mathrm{~s}^{-1} \text { after } 39 \text { minutes } \\
\text { at } \sim 0.15 \mathrm{k} \mathrm{m} \text { height }\end{array}$ & $\begin{array}{c}\sim-25 \mathrm{~m} \mathrm{~s}^{-1} \text { after } 27 \\
\text { minutes at } \sim 0.34 \mathrm{k} \mathrm{m} \\
\text { height }\end{array}$ \\
\hline
\end{tabular}

TABLE VI. The Condensed Cloud Water, Vertical Velocity and HEIGHT OF SURFACE HEATING EXPERIMENTS.

\begin{tabular}{|c|c|c|c|c|}
\hline \multicolumn{5}{|c|}{ The model without the deep convection approximation } \\
\hline Time $[\mathrm{min}]$ & $\begin{array}{c}\text { Condensed } \\
\text { cloud water } \\
{\left[\mathrm{g} \mathrm{m}^{-3}\right]}\end{array}$ & $\begin{array}{l}\text { Height } \\
{[\mathrm{k} \mathrm{m}]}\end{array}$ & $\begin{array}{c}\text { Vertical } \\
\text { velocity } \\
{\left[\mathrm{m} \mathrm{s}^{-1}\right]}\end{array}$ & $\begin{array}{l}\text { Height } \\
{[\mathrm{k} \mathrm{m}]}\end{array}$ \\
\hline 6 & 0.01 & 0.04 & -0.0004 & 0.20 \\
\hline 7 & 0.03 & & -0.0007 & 0.17 \\
\hline 8 & 0.05 & & -0.0012 & \\
\hline 9 & 0.06 & & -0.002 & \\
\hline 10 & 0.07 & & -0.003 & \\
\hline 11 & 0.09 & & -0.004 & $\vdots$ \\
\hline 12 & 0.11 & & -0.005 & \\
\hline 13 & 0.11 & & -0.005 & \\
\hline 14 & 0.13 & & -0.008 & \\
\hline 15 & 0.16 & & -0.008 & \\
\hline 16 & 0.16 & & -0.010 & 0.17 \\
\hline 17 & 0.18 & & -0.012 & 0.10 \\
\hline 18 & 0.20 & & -0.012 & \\
\hline 19 & 0.22 & & -0.012 & \\
\hline 20 & 0.22 & $\vdots$ & -0.015 & \\
\hline 21 & 0.24 & & -0.015 & \\
\hline 22 & 0.27 & & -0.015 & \\
\hline 23 & 0.27 & & -0.015 & \\
\hline 24 & 0.30 & & -0.015 & $\vdots$ \\
\hline 25 & 0.30 & & -0.020 & \\
\hline 26 & 0.33 & & -0.020 & \\
\hline 27 & 0.35 & & -0.020 & \\
\hline 28 & 0.35 & & -0.020 & \\
\hline 29 & 0.35 & & -0.020 & \\
\hline 30 & 0.40 & & -0.020 & \\
\hline 31 & 0.40 & & -0.020 & \\
\hline 32 & 0.40 & & -0.020 & \\
\hline 33 & 0.40 & & -0.025 & 0.10 \\
\hline 34 & 0.16 & & -0.250 & 0.04 \\
\hline 35 & 0.07 & & -0.500 & $\vdots$ \\
\hline 36 & $1.2 \times 10^{-5}$ & 0.04 & -0.200 & 0.04 \\
\hline
\end{tabular}

Tables II and VI, the model without the deep convection approximation gives condensed cloud water closed to normal low cloud. Cause surface cooling make the air more stable, the vertical velocities are quite small.

\section{Acknowledgment}

The author expresses the deepest gratitude to Prof. Robert Harold Buchanan Exell for his invaluable help, continued guidance, suggestions, comments, and discussions.

\section{References}

[1] C. Noisri and D. Sukawat, "Numerical model for studying cloud formation processes in the tropics," Australian Journal of Basic and Applied Sciences, vol. 5(2), 2011, pp. 189-193.

[2] C. Noisri and R. H. B. Exell, "A numerical model for studying convectional lifting processes in the tropics," World Academy of Science, Engineering and Technology, vol. 60, 2011, pp. 603-606.

[3] C. Noisri and R. H. B. Exell, "Developing a simple numerical model in moist air for studing cloud formation processes in the tropics," unpublished. [30th Conference on Hurricanes and Tropical Meteorology, Florida State University, Florida, USA, 2012].

[4] R. A. Pielke, Sr. Mesoscale Meteorological Modeling, 2nd ed, Academic press, San Diego, 2002, pp. 3-379.

[5] J. D. Anderson, Computational Fluid Dynamics, McGraw-Hill, New York, 1995, pp. 3-90.

[6] Rogers, R. R. and M. K. Yau, 1989: A Short Course In Cloud Physics, Butterworth-Heinemann, Woburn, 1989, pp. 1-80.

[7] R. H. B. Exell, "A Numerical Model for Small-Scale Meteorological Processes in the Topics-Version 2.1," 2009, unpublished.

\section{Creative Commons Attribution License 4.0} (Attribution 4.0 International, CC BY 4.0)

This article is published under the terms of the Creative Commons Attribution License 4.0

https://creativecommons.org/licenses/by/4.0/deed.en_US 